\title{
Nitrate levels in the surface waters collected in 2005 from intertidal and urban drainages of the west part of Peninsular Malaysia
}

\begin{abstract}
The intertidal and urban waters of west Peninsular Malaysia are interesting area for ecotoxicological studies because they receive wastes due to agricultural, municipal and industrial wastes along the west coast of Peninsular Malaysia. Surface water samplings were conducted from the intertidal coastal waters and from urban rivers/drainages from northern to southern parts of the west coastal areas of Peninsular Malaysia between January and April 2005. These nitrate levels in the south western part ranged from $0.33-0.56 \mathrm{mg} / \mathrm{L}$ while those in the north western part ranged from 0.11 to $1.91 \mathrm{mg} / \mathrm{L}$. These nitrate levels in these intertidal waters were much lower than those found for urban drainages $(0.45$ to $2.27 \mathrm{mg} / \mathrm{L}$ ) of Peninsular Malaysia. Overall, the mean values for the nitrate concentrations $(\mathrm{mg} / \mathrm{L})$ follow: Urban drainages $(1.04)>$ north western intertidal $(0.79)>$ south western intertidal (0.43). The results showed the occurrence of nitrate contamination in the urban area due to human-induced activities such as domestic wastes. Albeit this study revealed no serious threat of nitrate contamination in the urban and intertidal coastal waters compared to the safety limits, continuous monitoring should be carried out on the concentrations of nitrate in the aquatic ecosystem of Peninsular Malaysia since it could be a harmful nutrient to living organisms if presented in excessive concentrations.
\end{abstract}

Keywords: nitrate contamination, urban drainages, intertidal waters, west peninsular Malaysia
Volume 4 Issue 2 - 2020

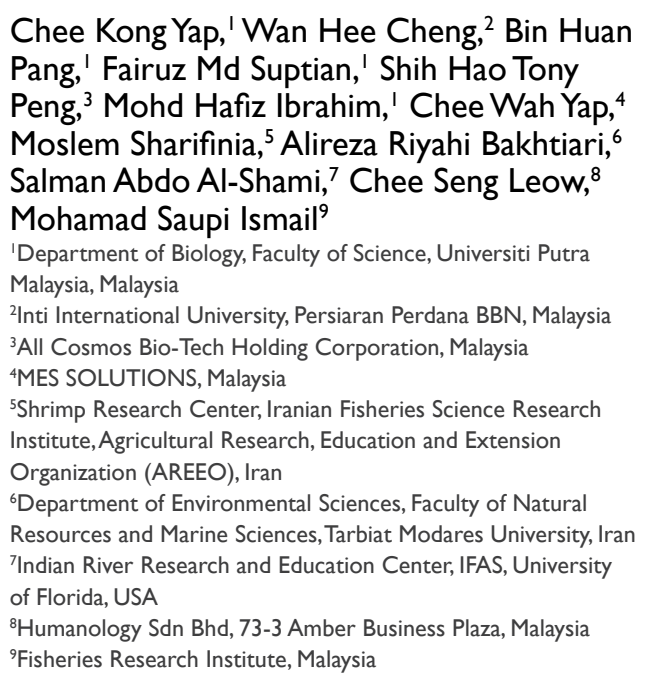

Correspondence: Chee Kong Yap, Department of Biology, Faculty of Science, Universiti Putra Malaysia, Malaysia, Email yapckong@hotmail.com

Received: February 02, 2020 | Published: March 04, 2020

\section{Introduction}

Monitoring the nitrate concentration in water courses will give us an idea of the extent of pollution from agricultural fertilizer run-off and might be used to predict the eutrophic state in such as those from China. ${ }^{1,2}$ The environmental concern on this nutrient are 1) it causes methemoglobinemia, a disease which could be totally prevented, 2) the toxicity effects of nitrate are especially susceptible to infants below the age of 4 months. ${ }^{3,4}$ and 3 ) the sources of water in rural areas are prone to nitrate contamination due to the increased usage of nitrate fertilizers. ${ }^{5}$

In the aquatic environment, natural events such as atmospheric and geological depositions, runoff from various water sources, fixation $\mathrm{N}_{2}$ and biological degradation of organic matter have brought upon the release of in organic nitrogen in their most reactive forms, namely ammonium $\left(\mathrm{NO}_{4}^{+}\right)$, nitrite $\left(\mathrm{NO}_{2}^{-}\right)$and nitrate $\left(\mathrm{NO}_{3}^{-}\right){ }^{6}$ Naturally, nitrate concentrations are found to be higher in the aquatic ecosystem as compared to ammonium and nitrite. ${ }^{7}$ These three reactive elements are eliminated by aquatic organisms which utilize them as a source of nitrogen. ${ }^{8}$ Nitrate acts as an inhibitor of oxygen carrying activities in aquatic organisms by transforming oxygen-carrying pigments (e.g., hemoglobin, hemocyanin) into inactive susbtances (e.g., methemoglobin). ${ }^{9}$
Consuming drinking water with high levels of nitrate causes detrimental health effects to human. As nitrate enters the biological system, especially in infants, it will be converted into nitrites which may halt the normal oxygen-carrying capacity of hemoglobin. ${ }^{10}$ This health complication is known as methemoglobinemia or 'blue baby' syndrome which occurs in infants and stomach cancer in adults. ${ }^{11}$ Apart from that, the formation of nitrosamines (a highly carcinogenic substance to mammals) take place in the digestive tract through ingestion of nitrates, adding to the risks of cancer. ${ }^{10}$ Previously, Yap et al. ${ }^{12}$ reported that the nitrate concentration in the offshore and intertidal coastal waters of the Straits of Malacca. However, an in depth study on nitrate levels in the rivers and drainages in Malaysia is very limited. Although nitrate has been a commonly known contaminant in ground water of agricultural areas but there is a lack of reported studies addressing this issue in tropical regions. ${ }^{3}$ This study evaluated the concentrations of $\mathrm{NO}_{3}{ }^{-} \mathrm{N}$ in surface water collected from some urban drainages and intertidal area from northern to southern parts of Peninsular Malaysia. The river water of these area received water runoff from agricultural activities (fertilization) and urban catchment (sewage) that may leach nitrate. ${ }^{13,14}$ On the other hand, Sigua et al. ${ }^{15}$ noted that the nitrogen and phosphorous availability for the requirement of maize plantations are greatly influenced by irrigation management decision and may possibly minimize the loss of nutrients from leaching. 
Knowing that nitrate contamination can serve as a useful indicator of overall water quality and since the information of nitrate in the river and drainage waters of west Peninsular Malaysia is lacking in the literature, this study aims to provide the status of nitrate contamination level in the waters of rivers, drainages and intertidal of west Peninsular Malaysia.

\section{Materials and methods}

Seawater samples were collected during three sampling periods The first sampling in January 2005 covered the southern part of
Peninsular Malaysia. The second sampling in April 2005 covered the northern part, while the third sampling (in April 2005) covered the central part of Peninsular Malaysia along the intertidal waters of west coastal areas. The sampling stations were established from Kuala Perlis in the north to the southern Johore. Triplicates of the surface water samples from each station were collected. For comparative purposes, water samples were collected from nine urban rivers water near a few townships. Information on the date of sampling and global positioning system (GPS) of each sampling site of the south western part, north western part and urban drainages of Peninsular Malaysia are given in Tables $1-3$, respectively.

Table I Date of sampling and GPS of each sampling site of the Intertidal waters of south western part of Peninsular Malaysia

\begin{tabular}{|c|c|c|c|c|c|}
\hline No. & Locations & $\begin{array}{l}\text { Date of } \\
\text { sampling }\end{array}$ & Longitude & Latitude & Description of site \\
\hline I & Kg. Pasir Puteh & 19-Jan-05 & N $01^{\circ} 26.00 I^{\prime}$ & E $103^{\circ} 55.326^{\prime}$ & A jetty \\
\hline 2 & Pantai Lido & 19-Jan-05 & N $01^{\circ} 28.144$ & E $103^{\circ} 43.553^{\prime}$ & A jetty \\
\hline 3 & Tanjung Piai (Tg. Piai) & I8-Jan-05 & $\mathrm{N} 01^{\circ} 16.925$ & E $103^{\circ} 30.585^{\prime}$ & A mangrove area \\
\hline 4 & $\begin{array}{l}\text { Kukup Jetty (near mussel culture site) } \\
\text { (Kukup-2) }\end{array}$ & I8-Jan-05 & $\mathrm{N} 01^{\circ} 19.550^{\prime}$ & E I03ㅇ․ $26.50 \mathrm{I}^{\prime}$ & A jetty \\
\hline 5 & Kukup Jetty (near jetty) (Kukup-I) & |8-Jan-05 & N $01^{\circ} 19.550^{\prime}$ & E $103^{\circ} 26.50 I^{\prime}$ & A jetty \\
\hline 6 & Sungai Senggarang & 18-Jan-05 & N $01^{\circ} 44.888$ & $\mathrm{EI} 03^{\circ} 03.18 \mathrm{I}^{\prime}$ & A river \\
\hline 7 & Sungai Rambah (Pontian) & I8-Jan-05 & $\mathrm{N} 01^{\circ} 25.790^{\prime}$ & E $103^{\circ} 25.018^{\prime}$ & A river \\
\hline 8 & Sungai Rambah (Sg. Pontian) & I8-Jan-05 & $\mathrm{N} 01^{\circ} 25.790^{\prime}$ & $\mathrm{E} 103^{\circ} 25.018^{\prime}$ & A river \\
\hline 9 & Pulau Ketam Jetty (J.P. Ketam-2) & 17-Jan-05 & $\mathrm{N} 03^{\circ} 01.213^{\prime}$ & E $101^{\circ} 21.733^{\prime}$ & An old and abandoned woody jetty \\
\hline 10 & Pulau Ketam Jetty (J.P. Ketam-I) & 17-Jan-05 & $\mathrm{N} 03^{\circ} 01.213^{\prime}$ & E $101^{\circ} 21.733^{\prime}$ & An old and abandoned woody jetty \\
\hline II & Sungai Ho/Ark & 17-Jan-05 & N $02^{\circ} 59.132^{\prime}$ & E $101^{\circ} 24.173^{\prime}$ & A boat repairing house \\
\hline 12 & Sungai Benut & 18-Jan-05 & N $01^{\circ} 39.095$ & E $103^{\circ} 15.158^{\prime}$ & A river \\
\hline 13 & Minyak Beku & I8-Jan-05 & N $01^{\circ} 47.732$ & E $102^{\circ} 53.327$ & A rocky shore \\
\hline 14 & Port Dickson Jetty & 17-Jan-05 & $\mathrm{N} 02^{\circ} 31.315^{\prime}$ & E $101^{\circ} 47.745^{\prime}$ & A jetty \\
\hline 15 & Sungai Lukut Besar & 17-Jan-05 & $\mathrm{N} 02^{\circ} 35.164^{\prime}$ & E $101^{\circ} 49.614^{\prime}$ & A mangrove area \\
\hline 16 & $\begin{array}{l}\text { Jetty Star Cruise, Pulau Indah (T.S. } \\
\text { Cruise) }\end{array}$ & 17-Jan-05 & N $02^{\circ} 59.157^{\prime}$ & E $101^{\circ} 20.317^{\prime}$ & $\begin{array}{l}\text { A rocky shore near a Terminal Star Cruise } \\
\text { platform }\end{array}$ \\
\hline 17 & Selat Lumut & 17-Jan-05 & $\mathrm{N} 02^{\circ} 58.730^{\prime}$ & E $101^{\circ} 23.000^{\prime}$ & A jetty \\
\hline 18 & Sungai Batu Pahat & 18-Jan-05 & N0I5I.48I' & E $102^{\circ} 55.460^{\prime}$ & A river \\
\hline 19 & Jetty Bandar Hilir Melaka (J.B. Hilir) & I7-Jan-05 & N $02^{\circ} 11.398^{\prime}$ & E $102^{\circ} 14.708^{\prime}$ & A jetty \\
\hline
\end{tabular}

Table 2 Date of sampling and GPS of each sampling site of the Intertidal waters of north western part of Peninsular Malaysia

\begin{tabular}{|c|c|c|c|c|c|}
\hline No. & Locations & Date of sampling & Longitude & Latitude & Description of site \\
\hline I & Tanjung Harapan & 25-Apr-05 & N 030.05.96' & E $101^{\circ} 21.637^{\prime}$ & A rocky recreational site \\
\hline 2 & Kapar Besar River & 25-Apr-05 & $\mathrm{N} 03^{\circ} 00.141^{\prime}$ & E $101^{\circ} 21.823^{\prime}$ & A mangrove area \\
\hline 3 & Janggut River & 25-Apr-05 & $\mathrm{N} 03^{\circ} 08.16 \mathrm{I}^{\prime}$ & 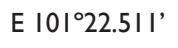 & A mangrove area \\
\hline 4 & Jeram River & 25-Apr-05 & 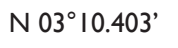 & E $101^{\circ} 18.819^{\prime}$ & A mangrove area \\
\hline 5 & Sg. Buloh & 25-Apr-05 & NA & NA & A mangrove area \\
\hline 6 & Kg. Kuantan & 18-Apr-05 & N $03^{\circ} 21.745^{\prime}$ & E $101^{\circ} 18.093^{\prime}$ & A jetty \\
\hline
\end{tabular}


Table continue

\begin{tabular}{|c|c|c|c|c|c|}
\hline No. & Locations & Date of sampling & Longitude & Latitude & Description of site \\
\hline 7 & Kg. Penambang & 18-Apr-05 & $\mathrm{N} 03^{\circ} 21.744^{\prime}$ & E I01이.096' & A jetty \\
\hline 8 & Sg. Bernam & 18-Apr-05 & $\mathrm{N} 03^{\circ} 21.599^{\prime}$ & E $101^{\circ} 14.965^{\prime}$ & A river \\
\hline 9 & Hutan Melintang & 18-Apr-05 & $\mathrm{N} 03^{\circ} 52.345^{\prime}$ & E $100^{\circ} 55.965^{\prime}$ & A mangrove area \\
\hline 10 & Pelabuhan Hutan Melintang & 18-Apr-05 & N $03^{\circ} 21.599^{\prime}$ & E I01 ${ }^{\circ} 14.965^{\prime}$ & An abandoned port \\
\hline II & Bagan Datoh & 18-Apr-05 & N $03^{\circ} 59.563^{\prime}$ & E $100^{\circ} 47.150^{\prime}$ & A rocky shore \\
\hline 12 & Lumut & 18-Apr-05 & N $04^{\circ} 14.145^{\prime}$ & E $100^{\circ} 37.854^{\prime}$ & A jetty \\
\hline 13 & J.R.P.Bainon & 18-Apr-05 & N $04^{\circ} 16.803^{\prime}$ & E $100^{\circ} 39.335^{\prime}$ & A river \\
\hline 14 & Kuala Kurau (K. Kurau) & 18-Apr-05 & $\mathrm{N} 05^{\circ} 00.928^{\prime}$ & $\mathrm{E} 100^{\circ} 25.867^{\prime}$ & An estuary \\
\hline 15 & Sg. Kuala Kurau (P.K.Kurau) & 18-Apr-05 & $\mathrm{N} 05^{\circ} 01.052^{\prime}$ & $\mathrm{E} 100^{\circ} 26.017^{\prime}$ & A river \\
\hline 16 & Jalan Pantai Kurau (K.Kurau J.) & 18-Apr-05 & N 05이.106' & E $100^{\circ} 24.779^{\prime}$ & A roadside drainage \\
\hline 17 & Tanjung (Tg.) Piandang & 18-Apr-05 & $\mathrm{N} 05^{\circ} 04.524^{\prime}$ & E $100^{\circ} 22.528^{\prime}$ & A mangrove area \\
\hline 18 & Bagan Tiang-I (B.Tiang-I) & 18-Apr-05 & $\mathrm{N} 05^{\circ} 08.517^{\prime}$ & E $100^{\circ} 22.459^{\prime}$ & Offshore \\
\hline 19 & BaganTiang-2 (J.B.Tiang)) & 18-Apr-05 & $\mathrm{N} 05^{\circ} 06.702^{\prime}$ & E $100^{\circ} 23.840^{\prime}$ & A small jetty \\
\hline 20 & Kuala Juru-2 (K. Juru-2) & 20-Apr-05 & $\mathrm{N} 05^{\circ} 20.410^{\prime}$ & E $100^{\circ} 24.518^{\prime}$ & Juru Estuary \\
\hline 21 & Kuala Muda (K. Muda) & 20-Apr-05 & N $05^{\circ} 34.343^{\prime}$ & E $100^{\circ} 21.735^{\prime}$ & A jetty \\
\hline 22 & Kuala Kedah Jetty (J.K. Kedah) & 20-Apr-05 & $\mathrm{N} 06^{\circ} 06.333^{\prime}$ & E $100^{\circ} 17.149^{\prime}$ & A jetty \\
\hline 23 & Kedah River (Sg. Kedah) & 20-Apr-05 & $\mathrm{N} 06^{\circ} 06.624^{\prime}$ & E $100^{\circ} 17.282^{\prime}$ & A jetty \\
\hline 24 & Sungai Berembang & 18-Apr-05 & $\mathrm{N} 06^{\circ} 21.313^{\prime}$ & E $100^{\circ} 08.787^{\prime}$ & A rocky shore \\
\hline 25 & Kuala Perlis & 18-Apr-05 & $\mathrm{N} 06^{\circ} 23.927^{\prime}$ & E $100^{\circ} 07.740^{\prime}$ & A jetty \\
\hline
\end{tabular}

Note: Not available

Table 3 Date of sampling and GPS of each sampling site of the urban drainages of west part of Peninsular Malaysia

\begin{tabular}{|c|c|c|c|c|c|}
\hline No. & Locations & Date of sampling & Longitude & Latitude & Description of site \\
\hline I & Klang-3 & 25-Apr-05 & $\mathrm{N} 03^{\circ} 01.120^{\prime}$ & E $101^{\circ} 22.453^{\prime}$ & An urban drainage \\
\hline 2 & Klang-2 & 25-Apr-05 & $\mathrm{N} 03^{\circ} 01.15 \mathrm{I}^{\prime}$ & E I0I $22.421^{\prime}$ & An urban drainage \\
\hline 3 & Klang-I & 25-Apr-05 & N $03^{\circ} 03.684^{\prime}$ & E I0Iํ30.347' & An urban drainage. Taman Rashna \\
\hline 4 & Shah Alam-2 & 25-Apr-05 & N 0303.683' & $\mathrm{E} 101^{\circ} 31.173^{\prime}$ & An urban drainage. \\
\hline 5 & Shah Alam-I & 25-Apr-05 & $\mathrm{N} 03^{\circ} 02.665^{\prime}$ & E $101^{\circ} 32.512^{\prime}$ & An urban drainage. \\
\hline 6 & Serdang & 25-Apr-05 & N 05²0.072' & E $100^{\circ} 26.080^{\prime}$ & An urban drainage. Besides JP Metal Factory \\
\hline 7 & Kuala Juru-3 & 20-Apr-05 & N $05^{\circ} 20.105^{\prime}$ & E $100^{\circ} 26.01 I^{\prime}$ & An urban drainage. Besides Packard Bell Factory \\
\hline 8 & Kuala Juru-I & 20-Apr-05 & N 05॰19.772' & E $100^{\circ} 26.083^{\prime}$ & An urban drainage. Juru industrial area near Juru River \\
\hline 9 & Alor Setar & $20-A p r-05$ & N 0607.420' & E $100^{\circ} 21.595^{\prime}$ & An urban drainage \\
\hline
\end{tabular}

Upon sample collection, the samples were immediately filtered by using filter paper Whatman No. 1 into preacid-washed pillboxes. Later, they were preserved with concentrated HCL below $\mathrm{pH}_{2}$ and were kept in a cool box $<4^{\circ} \mathrm{C}$ until transportation to laboratory. The nitrate level in seawater was determined according to the hydrazine reduction method. ${ }^{16}$ The prepared samples were measured for nitrate concentrations at the absorbance of 540nm using a spectrophotometer model Shimadzu UV 160. A calibration curve was prepared with known nitrate concentrations $(0.05 \mathrm{mg} / \mathrm{L}: 0.026 \mathrm{abs} ; 0.010 \mathrm{mg} /$ L:0.048abs; $0.30 \mathrm{mg} / \mathrm{L}: 0.132 \mathrm{abs} ; 0.50 \mathrm{mg} / \mathrm{L}: 0.212 \mathrm{abs})$ prepared from analytical grade $\mathrm{KNO}_{3}$. 


\section{Results}

The nitrate concentrations in the surface waters collected from the intertidal area of the south western part, north western part and urban drainages of Peninsular Malaysia are presented in Figures 1-3, respectively. These nitrate levels in the south western part ranged from $0.33-0.56 \mathrm{mg} / \mathrm{L}$ while those in the north western part were in the range of $0.11-1.91 \mathrm{mg} / \mathrm{L}$. These nitrate levels in these intertidal waters were much lower than those found for urban drainages $(0.45$ to $2.27 \mathrm{mg} / \mathrm{L}$ ) of Peninsular Malaysia. Overall, the mean values for the nitrate concentrations $(\mathrm{mg} / \mathrm{L})$ follow: Urban drainages $(1.04)>$ north western intertidal (0.79)> south western intertidal (0.43).

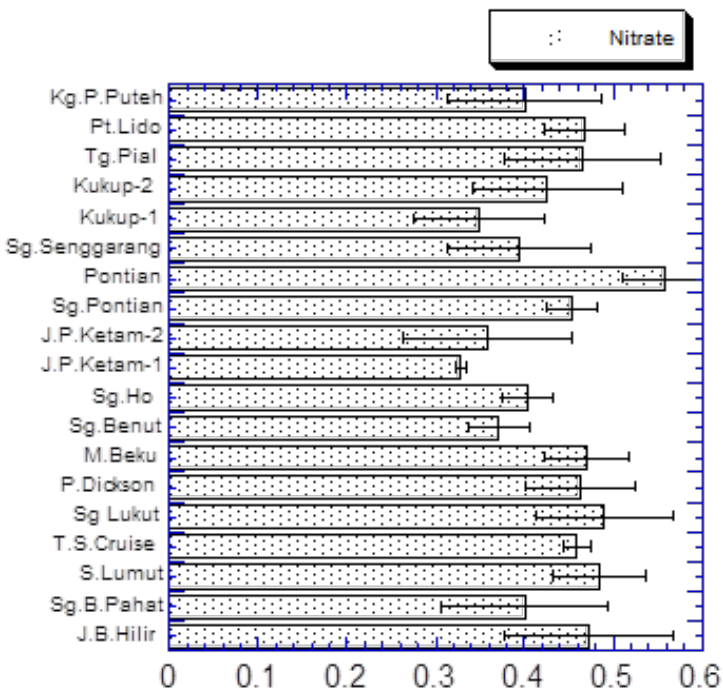

Figure I Nitrate concentrations $(\mathrm{mg} / \mathrm{L})$ in the surface waters collected from the intertidal area of the south western part of Peninsular Malaysia (19sampling sites)

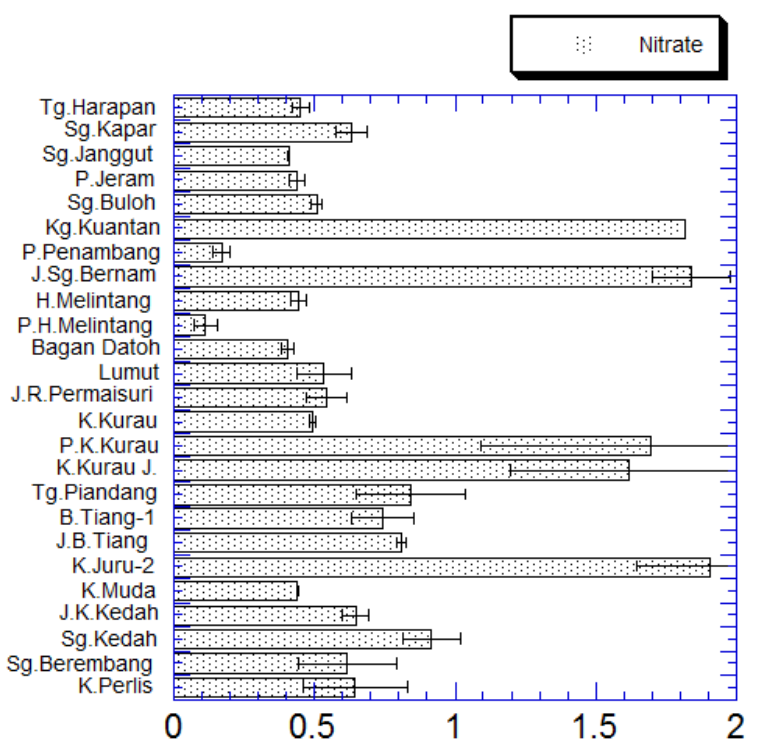

Figure 2 Nitrate concentrations $(\mathrm{mg} / \mathrm{L})$ in the surface waters collected from the intertidal area of the north western part of Peninsular Malaysia (25sampling sites).

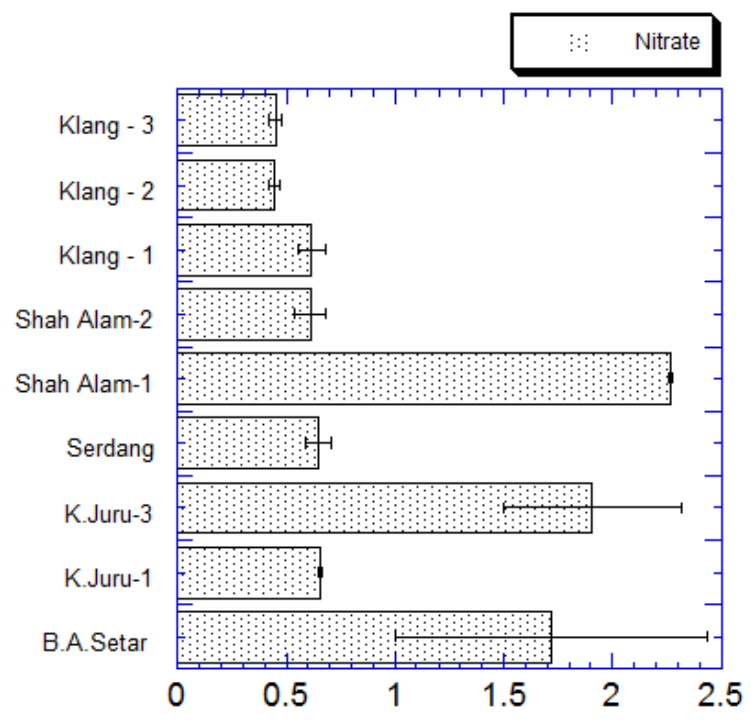

Figure 3 Nitrate concentrations $(\mathrm{mg} / \mathrm{L})$ in the surface waters from urban drainages of the west part of Peninsular Malaysia (9sampling sites).

\section{Discussion}

Yap et al. ${ }^{12}$ reported that the concentrations of nitrates in seawater were higher in samples collected from southern locations when compared to those collected from locations in the north. This was in contrast with the present result in which the northern part was found to have higher level of nitrate than those in the southern part as reported by Yap et al. ${ }^{12}$ These findings could be due to hydrologic factors such as raining that increased the dilution factor besides man-induced inputs.

Comparison of nitrate levels of the present results with those found in the seawater of coastal areas in the literature is presented in Table 4. Overall, the present results are lower and within those reported from the literature. Our nitrate concentrations are much lower than those reported by Ngenga ${ }^{17}$ for Nakuru Lake $(16-90 \mathrm{mg} / \mathrm{L})$ and for Naivasha Lake $(15-23.6 \mathrm{mg} / \mathrm{L})$ in Kenya and are comparable to those for Elementaita Lake $(0.12-0.15 \mathrm{mg} / \mathrm{L})$ and Kolleru Lake $(0.01-$ $1.47 \mathrm{mg} / \mathrm{L}$ ) during monsoon and non-monsoon in India. According to the Malaysian Guideline for Drinking Water Quality, ${ }^{18}$ the benchmark for nitrate level is $10.0 \mathrm{mg} / \mathrm{L}$. These nitrate levels are also considered low when compared with the acceptable nitrate level of $44.3 \mathrm{mg} / \mathrm{L}$ for public health intervention in the US. ${ }^{19}$ In the incident of Tianjin Port 8.12 explosion, a massive amount of nitrate were spewed into the coastal soil-water system causing harm to the wellbeing of both human and the environment. Liu et al. ${ }^{2}$ reported a concentration of nitrate at approximately $1000 \mathrm{mg} / \mathrm{L}$ within $5.0 \mathrm{~m}$ depth, exceeding the standard groundwater concentration which is $30 \mathrm{mg} / \mathrm{L}$.

It is interesting to document that higher levels of nitrate were found in the urban drainage waters when compared to those in the intertidal coastal waters and these results seem to be expected. The higher nitrate concentrations in urban drainage waters could be due to several reasons.

Municipal discharge and industrial wastes are the main contributors of concentrated nitrogen compounds into surface waters. The lower 
concentrations of nitrates in intertidal coastal waters than in the urban drainage waters could be due to dilution factor. However, it is noted that the main source of nitrogen $(\mathrm{N})$ in coastal ecosystems originated from anthropogenic sources..$^{20}$ The nitrate concentrations found in the intertidal coastal waters might be due to inland riverine discharges and atmospheric input of nitrate though precipitation. The higher levels of nitrates found in the city river and drainage waters, indicated that the nitrate contamination due to common sources such as livestock manure and chemical fertilizers for agricultural lands. Nitrate is an essential nutrient for aquatic plants including phytoplankton. ${ }^{21}$ In reservoirs and lakes, in the presence of large growth algae, the nitrate level can be rapidly depleted. Although the water samples collected and analyzed are not for direct human consumption, the comparison with WHO International Standard for drinking water is interesting for estimating the health risk if these water samples are being consumed by humans. Nitrates in high concentration in drinking water are harmful to human health. This is especially so for infants up to eight weeks who are fed with milk feed made up from water with a high nitrate content Cyanosis (methaemoglobinaemia) may develop, the so-called 'bluebaby' syndrome..$^{22}$ The excessive nitrate concentrations in the feed is not broken to ammonia, as is normal, but nitrite.

Table 4 Comparison of nitrate levels of the present results with those found in the seawater of coastal areas in the literature

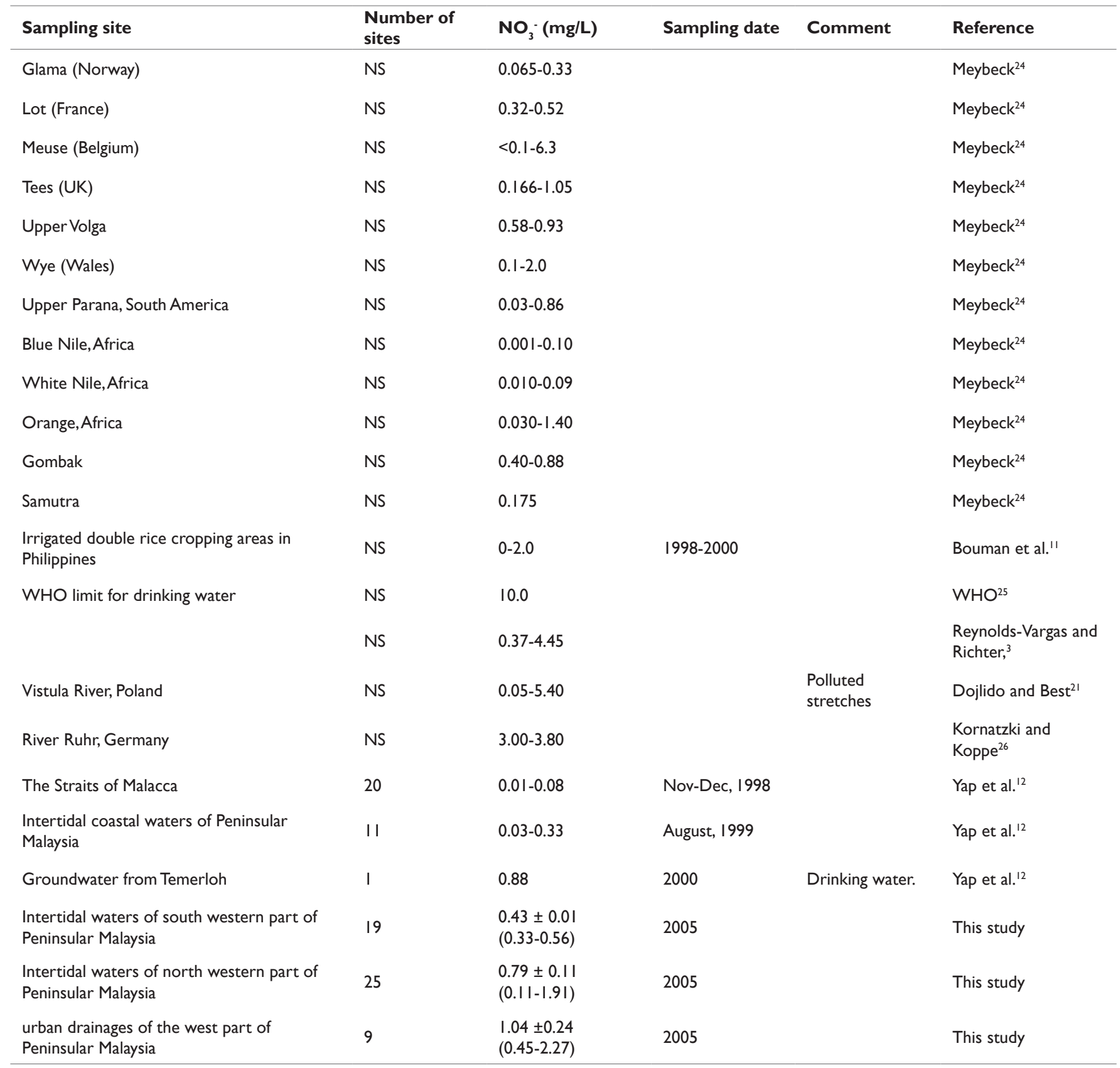

Note: NS=unspecified 
According to Segar and Hariharan, ${ }^{23}$ the elevated levels of nitrate is likely caused by effluents near the sampling sites while the low levels of nitrate near the coastal waters could also be resulted from dilution effects with considerable runoff, thus limiting the building of free nitrate in the water column. The increased concentration of nitrate near human activity sites indicated the distribution pattern was in conformity with the patterns found in most reported studies in the literature. Therefore, a comprehensive water quality monitoring on nitrate contamination should be conducted, expanding to all sources of drinking water in Malaysia in order to better identify possible sources of contamination. Measures to improve the potency of nitrogen fertilizer and modernize sewage management practices should be implemented to safeguard the water quality of these productive aquatic ecosystems. The sources of nitrate contamination may be derived mainly from fertilization and sewage contamination.

\section{Conclusion}

In conclusion, the comparison of spatial variations of nitrate concentrations between intertidal and urban drainage waters in the west coastal Peninsular Malaysia showed that nitrate contamination occurred in the urban area although it was not serious and could be considered as background at the time of sampling in January and April 2005. The present results could become very useful data for future reference. Since nitrates are of great toxicological interest due to their involvement in nitrites and nitrosamines formation. Thus, future monitoring of nitrate levels in the coastal and urban river waters of Peninsular Malaysia is necessary.

\section{Acknowledgments}

None.

\section{Conflicts of interest}

The authors declare that there is no conflict of interest.

\section{Funding}

None.

\section{References}

1. Hu K, Huang YF, Li H, et al. Spatial variability of shallow groundwater level, electrical conductivity and nitrate concentration, and risk assessment of nitrate contamination in North China Plain. Environment International. 2005;31(6):896-890.

2. Liu L, Liang S, Liu H, et al. Nitrate contamination in a coastal soil and water system: A case study after the Tianjin Port $8 \cdot 12$ explosion, China. Human and Ecological Risk Assessment. 2019;25(8):2017-2031.

3. Reynolds-Vargasa JS, Richter BDD. Nitrate in groundwaters of the Central Valley, Costa Rica. Environ Int. 1995;21(1):71-79.

4. Ramos C, Agut A, Lidon AL. Nitrate leaching in important crops of the Valencian Community region (Spain). Environ Pollut. 2002;118(2):215223.

5. Shaw IC, Chadwick J. Principles of environmental toxicology. Taylor and Francis, London. 1998. p. 67.

6. Wetzel RG. Limnology. $3^{\text {rd }}$ edition. New York: Academic Press; 2001

7. Rabalais NN. Nitrogen in aquatic ecosystems. Ambio. 2002;31(2);102112.

8. Nixon SW. Coastal marine eutrophication: a definition, social causes, and future concerns. Ophelia. 1995;41(1):199-219.
9. Cheng SY, Chen JC. Study on the oxyhemocyanin, deoxyhemocyanin, oxygen affinity and acid-base balance of Marsupenaeus japonicus following exposure to combined elevated nitrite and nitrate. Aquatic Toxicol. 2002;61(3-4):181-193.

10. Caballero Mesa JM, Rubio Armendariz C, Hardisson de la Torre A. Nitrate intake from drinking water on Tenerife island (Spain). Sci Tot Environ. 2002;302(1-2):85-92.

11. Bouman BAM, Castaneda AR, Bhuiyan SI. Nitrate and pesticide contamination of groundwater under rice-based cropping systems: past and current evidence from the Philippines. Agriculture, Ecosystems and Environment. 2002;92(2-3):185-199.

12. Yap CK, Ismail A, Misri K, et al. Nitrate Concentrations in the Surface Seawater of the Straits of Malacca. Asian Journal of Water, Environment and Pollution. 2005;2(2):45-49.

13. Adams PL, Daniel TC, Edwards DR, et al. Poultry litter and manure contributions to nitrate leaching through the vadose zone. Soil Sci Soc Am J. 1994;58(4):1206-1211.

14. Chang C, Entz T. Nitrate leaching losses under repeated cattle feedlot manure applications in Southern Alberta. J Environ Qual. 1996;25(1):145-153.

15. Sigua GC, Stone KC, Bauer PJ, et al. Impacts of irrigation scheduling on pore water nitrate and phosphate in coastal plain region of the United States. Agricultural Water Management. 2017;186:75-85.

16. Kitamura $\mathrm{H}$, Ishitani $\mathrm{H}, \mathrm{Kuge} \mathrm{Y}$, et al. Determination of nitrate freshwater and seawater by a hydrazine reduction method. Japan J Wat Pollut Res. 1982;5(1):35-42.

17. Ngenga JW. Comparative studies of water chemistry of four tropical lakes in Kenya and India. Asian Journal of Water, Environment and Pollution. 2004;1(12):87-97.

18. DOE (Department of Environment). Malaysia Environmental Quality Report 2000. DOE Ministry of Science, Technology and the Environment Malaysia. MASKHA Sdn Bhd. 2001. p. 85.

19. Levallois $P$, Theriault M, Rouffignat J, et al. Groundwater contamination by nitrates associated with intensive potato culture in Quebec. Sci Tot Environ. 1998;217(1-2):91-101.

20. Dong Z, Wang K, Chen X, et al. Temporal dynamics of bacterioplankton communities in response to excessive nitrate loading in oligotrophic coastal water. Marine Pollution Bulletin. 2017;114(2):656-663.

21. Dojlido J, Best GA. Chemistry of water and water pollution. New York: Ellis Horwood; 1993. p. 121.

22. Donovan JW. Nitrates, nitrites, and other sources of methemoglobinemia. In: Haddad LM, Winchester JF, editors. Clinical management of poisoning and drug overdose. $2^{\text {nd }}$ edition. Philadelphia: WB Saunders. 1990;1419-1431.

23. Segar K, Hariharan V. Seasonal distribution of nitrate, nitrite, ammonia and plankton in effluent discharge areas off Mangalore, west coast of India. Indian Journal of marine Science. 1989;18(3):170-173.

24. Meybeck M. Carbon, nitrogen, and phosphorus transport by world rivers. Am J Sci. 1982;282:401-450.

25. WHO (World Health Organization). Health hazards from nitrates in drinking water. Geneva: World Health Organization. 1985.

26. Kornatzki KH, Kppe P. The question of the nitrate content of running water is shown on the example of the ammonium compounds. Vom Wasser. 1981;45:103. 